Blair, 1960). It is now well established that it is the oestrogens which appear to be responsible for the adverse effects on clotting and platelet function (Poller et al., 1971a, 1971b) and for the thrombotic tendency (Inman et al., 1970). The 19-norsteroid might in theory therefore have produced similar changes to oestrogen-containing oral contraceptives.

The lack of adverse effects on blood clotting with norethisterone is in contrast to our previous findings with all types of conventional combined oral contraceptives where significant rises of factors VII and $\mathrm{X}$ as well as other undesirable clotting changes occurred within the first three months of administration. In addition, we have found accelerated cephalin times and Chandler's tube platelet aggregation times with combined preparations. A number of authors have found a tendency to increased platelet adhesion (Ygge et al., 1969) with combined preparations. Von Kaulla and von Kaulla (1970) showed a fall in antithrombin III levels with conventional oral contraception. Several authors have also reported rises in fibrinogen levels with oestrogen-progestogen administration (Nilsson and Kullendar, 1967). The lack of such changes with six months' norethisterone administration is reassuring.

In a previous long-term follow-up of a group taking chlormadinone acetate no change in clotting tests was recorded but acceleration of the Chandler's tube platelet aggregation test was recorded after two years, although this was significantly less then a long-term group on combined ostrogen-progestogen preparations. Longer follow-up will therefore be required to be certain that delayed or cumulative effects do not occur at a later stage of the present study of norethisterone administration.

The absence of adverse effects on clotting and platelets in the group of women not previously having taken oral contraceptives was also supported by the absence of changes in women who changed to norethisterone from chlormadinone acetate and the small group of postpartum patients. None of the patients in this trial suffered from thrombosis but this was unlikely in view of the small size of the groups tested. The absence of clotting and platelet changes is not proof that oral contraception with 19-norsteroid progestogens will be devoid of thrombotic complications, but the evidence that these undesirable side effects on clotting have been avoided raises the possibility of a reduction in thromboembolic risk when they are used instead of combined preparations.

The work was performed while in receipt of a long-term grant from the Medical Research Council. Gratitude is expressed to Syntex Pharmaceuticals for supplies of norethisterone and a grant for technical help.

Lesley Eaton and Joy Holley provided additional technical help in this investigation.

\section{References}

Abilgaard, U., Graven, K., and Godal, H. C. (1970), Thrombosis et Diathesis Haemorrhagica, 24, 224.

Brown, J. B., and Blair, H. A. F. (1960). Proceedings of the Royal Society of Medicine, 53, 433.

Burslem, R. W., Gough, D., and Mandara, M. (1972). To be published. Hirsh, J., and McBride, J. A.' (1965). British Medical fournal, 2, 797.

Inman, W. H., Vessey, M. P., Westerholm, B., and Engelund, A. (1970) British Medical fournal, 2, 203.

Kaulla, E. von, and Kaulla K. N. von (1970). Lancet, 1, 36.

Leavelle, Dennis E., Mertins, B. F., Bowie, W. E. J., and Owen, C. A., jun (1971). American fournal of Clinical Pathology, 55, 452

Merskey, C., Lalezari, P., and Johnson, A. J. (1969). Proceedings of the Society for Experimental Biology and Medicine, 131, 871.

Nilsson, I. M., and Kullander, S. (1967). Acta Obstetricia et Gynecologica Scandinavica, 46, 286

Poller, L., Tabiowo, Anne, Thomson, Jean M. (1968). British Medical fournal, 3, 218.

Poller, L., Thomson, Jean M., Tabiowo, Anne, and Preist, Celia M. (1969). British Medical fournal, 1, 554.

Poller, L., Thomson, Jean M., Thomas, Wendy, and Wray, Carol (1971a). British Medical fournal, 1, 705.

Poller, L., Thomson, Jean M., and Thomas, Wendy (1971b). British Medical fournal, 4, 648 .

Poller, L., Thomson, Jean M., Sear, C. H. J., and Thomas, Wendy (1971c). Fournal of Clinical Pathology, 24, 626

Thomson, Jean M., and Poller, L. (1965). British Medical fournal, 2, 270

Ygge, J., Brody, S., Korsan Bengsten, K., and Nilsson, L. (1969). American fournal of Obstetrics and Gynecology, 104, 87.

\title{
Glucose Tolerance and Insulin Secretion in Patients with Chronic Duodenal Ulcer
}

\author{
C. S. HUMPHREY， J. R. W. DYKES， D. JOHNSTON
}

British Medical fournal, 1972, 4, 393-396

\section{Summary}

An oral glucose tolerance test has been used to compare carbohydrate metabolism in patients suffering from chronic duodenal ulceration with that in a matched group of normal subjects. A significantly greater rise in blood glucose concentration was observed in the duodenal ulcer group, and this was associated with a significantly greater output of insulin. The reason for these findings may be an abnormal secretion of one or more of the smallbowel hormones.

\section{Introduction}

Abnormal glucose tolerance curves have been described after both partial gastrectomy and vagotomy and drainage, and have been attributed in large part to abnormally rapid gastric empty-

University Departments of Surgery and Chemical Pathology, The General Infirmary, Leeds

C. S. HUMPHREY, M.B., CH.B., Research Assistant, Honorary Registrar J. R. W. DYKES, M.B., CH.B., Lecturer

D. JOHNSTON, M.B., F.R.C.S., Reader in Surgery ing (Evensen, 1942; Cameron et al., 1969; Holdsworth et al., 1969; Perreau et al., 1969). Less attention has been paid to the question of carbohydrate metabolism in the preoperative ulcer patient. Early studies yielded conflicting results, probably because the techniques of the glucose tolerance tests were not standardized and the methods used for estimating blood glucose concentrations were relatively crude. Furthermore, changes in plasma insulin levels could only be inferred from the observed variations in blood glucose concentration.

The importance of the gastrointestinal hormones in modifying the insulin response to ingested carbohydrate is established (McIntyre et al., 1964, 1965). The altered gastrointestinal physiology accompanying chronic peptic ulcer disease might be reflected in an abnormal pattern of carbohydrate metabolism. We have used an oral glucose tolerance test with measurement of blood glucose and plasma insulin concentrations to investigate a group of patients with chronic duodenal ulcer in an attempt to define any such abnormality.

\section{Patients and Methods}

Fifteen patients with a lengthy history of dyspepsia, in whom a radiological diagnosis of chronic duodenal ulcer had been 
obtained, formed the test group. All of these patients were operated on and the diagnosis was confirmed. None was suffering from any of the complications of duodenal ulceration. An additional five subjects with severe pyloric stenosis secondary to duodenal ulceration were studied. The control group comprised 15 healthy subjects, either colleagues or patients admitted to hospital for minor surgical procedures. None had diabetes. All of the patients and controls were within $10 \%$ of their ideal body weight and had been taking a normal diet before the test. Details of the subjects are shown in Table I.

TABLE I-Details of Subjects (Mean \pm 1 S.E. of Mean)

\begin{tabular}{|c|c|c|c|c|c|c|}
\hline & & \multirow{2}{*}{$\underset{\text { (years) }}{\text { Age }}$} & \multirow{2}{*}{$\begin{array}{c}\text { Height } \\
\text { (m) }\end{array}$} & \multirow{2}{*}{$\underset{(\mathbf{k g})}{\text { Weight }}$} & \multicolumn{2}{|c|}{ Sex } \\
\hline & & & & & M. & F. \\
\hline Duodenal ulcer & $\ldots$ & $45 \cdot 4 \pm 3 \cdot 41$ & $1.71 \pm 0.21$ & $65 \cdot 3 \pm 2 \cdot 7$ & 11 & 4 \\
\hline Control & .. & $40 \cdot 7 \pm 4 \cdot 3$ & $1 \cdot 70 \pm 0 \cdot 25$ & $66 \cdot 5 \pm 2 \cdot 9$ & 10 & 5 \\
\hline
\end{tabular}

Procedure.-After fasting overnight the subject drank $350 \mathrm{ml}$ of a $25 \%$ glucose solution as rapidly as possible. The first 10 minutes of the two-hour test were carried out with the subject standing, the remainder of the test with the subject sitting upright. Venous blood samples wereobtained through an indwelling heparinized cannula before the the test and then at 10,20,30,45, 60,90 , and 120 minutes. Blood glucose concentrations were meassured by the glucose oxidase method of Morley et al. (1968), the coefficient of variation being $4 \cdot 6 \%$ at a blood glucose concentration of $105 \mathrm{mg} / 100 \mathrm{ml}$. Plasma immunoreactive insulin was measured in duplicate by the method of Hales and Randle (1963) using a radioactive iodinated insulin and Oxoid membrane filters supplied by the Radiochemical Centre at Amersham. The pre-precipitated antibody and standard human insulin were supplied by Burroughs Wellcome. This assay method gave results with the following standard deviations: $\pm 2.92 \mu \mathrm{U} / \mathrm{ml}$ for 115 duplicate determinations in the range $0-49 \mu \mathrm{U} / \mathrm{ml}$; $\pm 6.51 \mu \mathrm{U} / \mathrm{ml}$ for 64 determinations in the range $50-99 \mu \mathrm{U} / \mathrm{ml}$; and $\pm 7.25 \mu \mathrm{U} / \mathrm{ml}$ for 55 determinations in the range 100$200 \mu \mathrm{U} / \mathrm{ml}$. Samples with a plasma insulin concentration of more than $200 \mu \mathrm{U} / \mathrm{ml}$ were diluted and reassayed. With this exception all specimens from any one subject were assayed in the same batch.

\section{Results}

The changes in blood glucose and plasma insulin concentrations occurring during the test in the normal subjects and duodenal ulcer patients are shown in Figs. 1 and 2 and are summarized in Table II. The ulcer patients exhibited a hyperglycaemia and

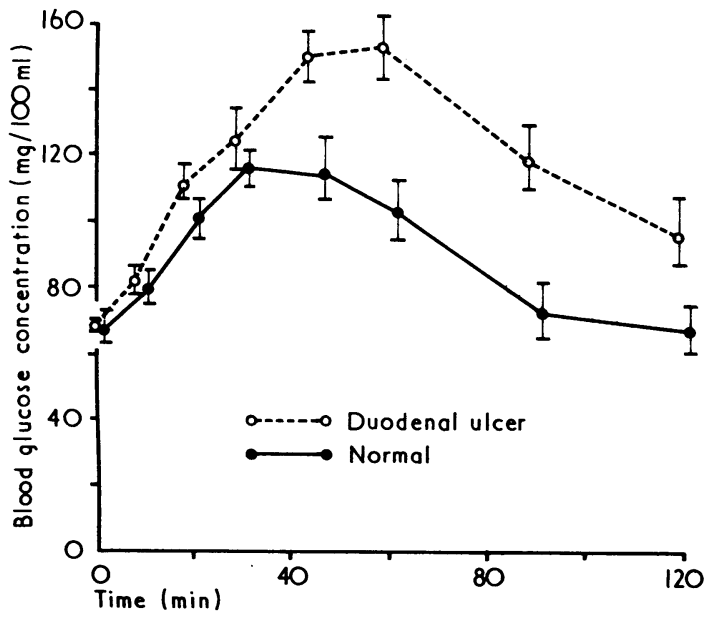

FIG. 1-Blood glucose concentrations in 15 normal subjects and 15 patients with chronic duodenal ulcer in response to $350 \mathrm{ml}$ of $25 \%$ glucose. Mean values \pm 1 S.E. of mean.

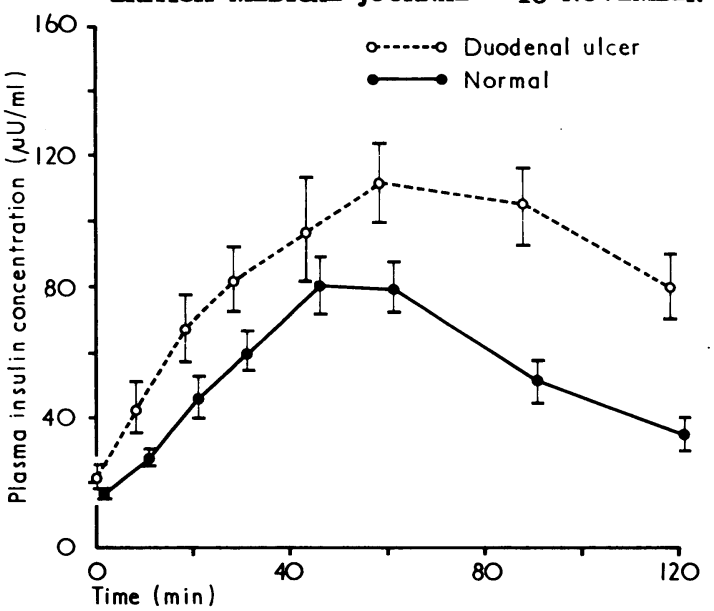

FIG. 2-Plasma insulin concentrations in 15 normal subjects and 15 patients with chronic duodenal ulcer in response to $350 \mathrm{ml}$ of $25 \%$ glucose. Mean values \pm 1 S.E. of mean.

TABLE II-Details from Blood Glucose and Plasma Insulin Curves (Mean values \pm 1 S.E. of Mean)

\begin{tabular}{|c|c|c|c|c|c|}
\hline & \multicolumn{3}{|c|}{ Blood Glucose $(\mathrm{mg} / 100 \mathrm{ml})$} & \multicolumn{2}{|c|}{ Plasma Insulin $(\mu \mathrm{U} / \mathrm{ml})$} \\
\hline & Maximum & Minimum & $\begin{array}{l}\text { Area Under } \\
\text { Curve } \\
\text { (0-120 min) }\end{array}$ & Maximum & $\begin{array}{l}\text { Area Under } \\
\text { Curve } \\
\text { (0-120 min) }\end{array}$ \\
\hline $\begin{array}{l}\text { Duodenal } \\
\text { ulcer } \\
\text { Control }\end{array}$ & $\begin{array}{l}163 \cdot 0 \pm 8 \cdot 6 \\
123 \cdot 2 \pm 7 \cdot 2\end{array}$ & $\left|\begin{array}{r}92 \cdot 7 \pm 10 \cdot 2 \\
63.5 \pm 6.4\end{array}\right|$ & $\begin{array}{r}6,503 \cdot 9 \pm 691 \cdot 3 \\
3,031 \cdot 5 \pm 563 \cdot 4\end{array}$ & $\mid \begin{array}{r}130.7 \pm 11.3 \\
90.3 \pm 6.9\end{array}$ & $\begin{array}{l}7,638 \cdot 1 \pm 856 \cdot 3 \\
4,125 \cdot 6 \pm 621 \cdot 2\end{array}$ \\
\hline
\end{tabular}

hyperinsulinaemia, the form of the two curves being similar. Blood glucose concentrations were significantly raised above control levels at 45, 60, 90, and $120 \mathrm{~min}(\mathrm{P}<0.05, P<0.01$, $P<0.01$, and $P<0.05)$. Significantly increased plasma insulin concentrations were found at 60,90 , and $120 \mathrm{~min}(P<0.05$, $P<0.001$, and $P<0.001$ ).

Total insulin secretion was estimated by computing the area beneath the plasma insulin curve from 0 to 2 hours (Perley and Kipnis, 1965). Similarly the area beneath the blood glucose curve from 0 to 2 hours was measured to give an index of glucose tolerance (Burns et al., 1965; Bagdade et al., 1967). A decrease in this area represents an improvement in glucose tolerance. The results of these measurements are shown in Table II. Insulin secretion over the two-hour period was significantly increased in the ulcer patients $(P<0.01)$, yet despite this glucose tolerance was impaired in these patients as is shown by increased areas beneath the blood glucose curves ( $P<0.001)$. According to the criteria laid down by the British Diabetic association (Fitzgerald and Keen, 1964), six of the

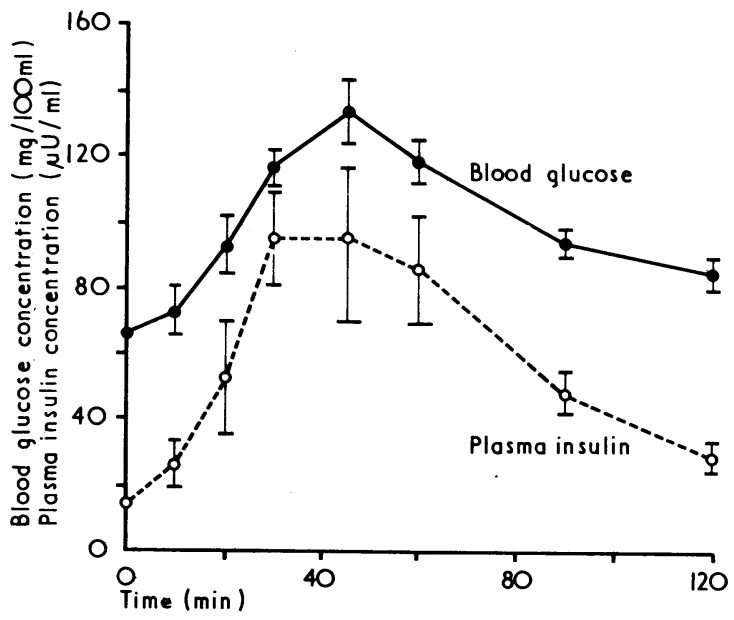

FIG. 3-Blood glucose and plasma insulin concentrations in five paticnts with chronic duodenal ulcer complicated by pyloric stenosis. Mean values \pm 1 S.E. of mean. 
duodenal ulcer patients ( $40 \%$ ) exhibited abnormal glucose tolerance compared with only one of the control group (6.7\%).

The blood glucose and plasma insulin levels found in the five patients with pyloric stenosis secondary to duodenal ulcer are shown in Fig. 3. The results show a pattern intermediate between the pronounced hyperglycaemia and hyperinsulinaemia of the patients with uncomplicated duodenal ulcer and the normal glucose tolerance and insulin secretion of the control group.

\section{Discussion}

An abnormal hyperglycaemic response to oral glucose has been described previously in patients with chronic duodenal ulcer (Evensen, 1942; Abrahamson, 1945; Platt et al., 1949). In a more recent study, however, Buchanan et al. (1967) found that although blood sugar concentrations were higher after oral glucose in patients with duodenal ulcer than in a group of control subjects, the difference attained statistical significance only at 15 minutes after the test began. Despite this they were able to show that the ulcer patients had an insulin output which was significantly greater than that in the control group.

The abnormalities of carbohydrate metabolism which we have found in patients with chronic duodenal ulcer could conceivably be a reflection of a more generalized metabolic disorder. Impaired glucose tolerance with associated hyperinsulinaemia has been described in patients with cirrhosis (Berkowitz et al., 1969) and obesity (Yalow et al., 1965; Bagdade et al., 1967; Abrams et al., 1969). Glucose tolerance and insulin secretion are affected in a similar way by excessive corticosteroid and growth hormone secretion (Berger et al., 1966; Oakley et al., 1970). None of the present patients had any clinical evidence of these disorders, and all had normal liver function tests. Hall (1971) was unable to show any evidence of abnormal growth hormone secretion in patients with duodenal ulcer. The present patients were all within $10 \%$ of their ideal body weight and taking a normal diet.

Griffith et al. (1968) suggested that patients with uncomplicated duodenal ulcer have an abnormally rapid rate of gastric emptying soon after a meal. Rapid gastric emptying is known to result in a faster rate of rise of blood glucose concentration and higher peak levels in patients who have undergone partial gastrectomy or vagotomy and a drainage procedure (Evensen, 1942; Cameron et al., 1969; Holdsworth et al., 1969; Perreau et al., 1969). However, as the raised peak blood glucose levels are followed by an exaggerated fall towards hypoglycaemia this explanation alone will not account for the results which we have obtained in patients with duodenal ulcer. Conversely, a slower rate of gastric emptying might be expected to give a more prolonged (albeit somewhat flatter) hyperglycaemia phase, such as we have observed in the patients with duodenal ulcer. The results which we have obtained in patients with delayed emptying of the stomach due to pyloric stenosis are against this explanation, showing as they do a pattern intermediate between that of the duodenal ulcer and normal patients, rather than an exaggeration of the ulcer pattern.

A further explanation for the present results is suggested by a consideration of the part that the gastrointestinal hormones play in determining the plasma insulin response to oral glucose. Gastrin, secretin, gut glucagon, and cholecystokinin have all been shown to be released by oral glucose and to augment the output of insulin from the pancreas (Samols et al., 1965; Young et al., 1968; Dupre et al., 1969; Rehfeld and Heding, 1970). It is for this reason that the insulin response to oral glucose is of a greater magnitude than that to a corresponding intravenous glucose challenge (McIntyre et al., 1964; Dupre, 1964). It may be that the altered gastrointestinal physiology which accompanies duodenal ulceration-in particular the hypersecretion of acid-is accompanied by an increased release of one or more of these hormones. There is some evidence to suggest that the presence of acid in the duodenum increases the secretion of insulin from the pancreas (Dupre, et al., 1969; Kaess et al., 1970) although this has been denied (Boyns et al., 1966). Chisholm et al. (1969) perfused the duodenum with acid in normal subjects and observed a prompt release of secretin into the blood stream which was followed by a rise in plasma insulin concentrations. Buchanan and his co-workers (1967) were unable to find any correlation between gastric acid secretion and plasma insulin levels in their duodenal ulcer patients. We have compared the basal acid secretion in the 11 male duodenal ulcer subjects with the total insulin output over the two-hour test period (Table III). There is a significant positive correlation between these two criteria $(P<0.01)$ although the relation is not a linear one (Fig. 4). The abnormal insulin

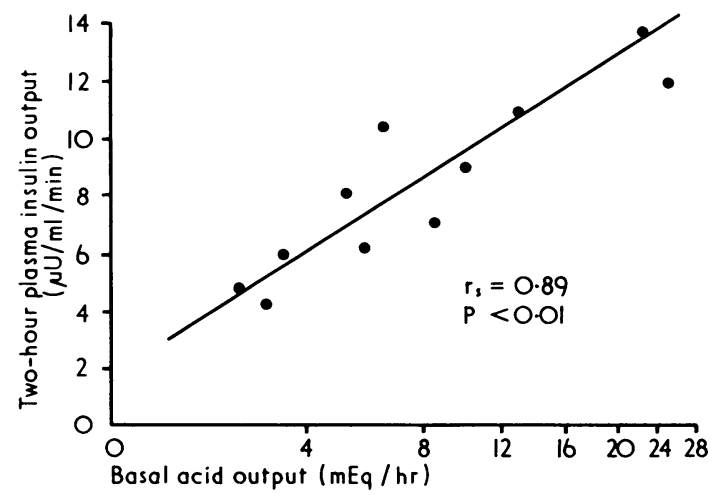

FIG. 4-Correlation between two-hour insulin response to $350 \mathrm{ml}$ of $25 \%$ glucose and basal acid output in 11 male patients with chronic duodenal ulcer. Rank correlation calculated by the method of Spearman (1904). Basal acid output plotted on a logarithmic scale.

response to oral glucose is particularly pronounced in those duodenal ulcer patients who exhibit high levels of basal acid secretion. The finding of hyperglycaemia at a time when plasma insulin levels are raised, suggesting a degree of resistance to the peripheral actions of insulin, is in keeping with the concept of an increased release of small-bowel hormones, since some of these hormones are known to exert, either directly or indirectly, a hyperglycaemic effect (Unger and Eisentraut, 1964; Unger et al., 1967; Ohgawara et al., 1969).

It has been suggested that hyperinsulinaemia may be a factor in the aetiology of duodenal ulceration (Buchanan et al., 1967) acting via the vagus nerves to cause hypersecretion of acid by the stomach. This wculd seem unlikely since it is not insulin per se but rather hypoglycaemia that stimulates gastric secretion (Okada et al., 1930; Roholm, 1930).

Hobsley and Le Quesne (1960) and Sullivan and Boshell (1964) have suggested that a postabsorptive abnormality of carbohydrate metabolism may play a part in the genesis of the dumping syndrome which some patients experience after gastric surgery. Both insulin (Hobsley and Le Quesne, 1960) and oral hypoglycaemic agents (Sullivan and Boshell, 1964) have been used to ameliorate the symptoms of dumping. While we have shown raised concentrations of plasma insulin in the duodenal ulcer patients, these would seem to be relatively ineffective from the point of view of disposing of the glucose load. It may be that the patients who have abnormal glucose tolerance are those who are predisposed to dumping symptoms after operation.

TABLE III-Basal Acid Output and Two-hour Insulin Output in 11 Male Patients with Chronic Duodenal Ulcer

\begin{tabular}{|c|c|c|c|c|c|c|c|c|c|c|c|c|}
\hline $\begin{array}{l}\text { Basal acid output (mEq/hr) .. } \\
\text { Two-hour plasma insulin output } \\
\mu \mathrm{U} / \mathrm{ml} / \mathrm{min})\end{array}$ & $\begin{array}{l}\cdots \\
\cdots\end{array}$ & $\begin{array}{r}2 \cdot 26 \\
4,473\end{array}$ & $\begin{array}{r}3.08 \\
4,248\end{array}$ & $\begin{array}{l}3.42 \\
6,040\end{array}$ & $\begin{array}{r}5 \cdot 32 \\
8,120\end{array}$ & $\begin{array}{l}5 \cdot 82 \\
6,230\end{array}$ & $\begin{array}{c}6 \cdot 68 \\
10,618\end{array}$ & $\begin{array}{r}8 \cdot 68 \\
7,078\end{array}$ & $\begin{array}{r}9 \cdot 92 \\
9,051\end{array}$ & $\begin{array}{l}12 \cdot 89 \\
10,520\end{array}$ & $\begin{array}{l}22 \cdot 48 \\
13,876\end{array}$ & $\begin{array}{l}25 \cdot 30 \\
11,923\end{array}$ \\
\hline
\end{tabular}


There is evidence to suggest that peptic ulceration and cardiovascular disease occur together more commonly than would be expected by chance. Abdominal aortic aneurysm has been linked with peptic ulcer disease (Jones et al., 1970; British Medical fournal, 1971), and both Allan and Dawson (1968) and Hall et al. (1971) described a high incidence of duodenal ulceration in patients with coronary heart disease and peripheral vascular disease respectively. Sloan et al. (1970) described a pattern of impaired glucose tolerance and hyperinsulinaemia in patients with peripheral atherosclerosis, whish is similar to the results which we have obtained in patients with duodenal ulcer before operation. An increased insulin response to oral glucose has also been described in patients surviving myocardial infarction (Peters and Hales, 1965). Stout (1968) has shown in experimental animals that insulin stimulates both lipogenesis and cholesterol synthesis in arterial tissue. There are many possible reasons why duodenal ulcer disease and vascular disease may be related. The present results suggest that abnormal carbohydrate metabolism may be common to both.

\section{References}

Abrams, M. E., Jarrett, R. J., Keen, H., Boyns, D. R., and Crossley, J. N. (1969). British Medical Fournal, 1, 599.

Abrahamson, E. M. (1945). American fournal of Digestive Diseases, 12, 379. Allan, T. M., and Dawson, A. A. (1968). British Heart fournal, 30, 377 Bagdade, J. D., Bierman, E. L., and Porte, D. (1967). Fournal of Clinical Investigation, 46, 1549.

Berger, S., Downey, J. L., Traisman, H. S., and Metz, R. (1966). New England Fournal of Medicine, 274, 1460 .

Berkowitz, D. (1969). American fournal of Digestive Diseases, 14, 691.

Boyns, D. R., Jarrett, R. J., and Keen, H. (1966). Lancet, 1, 409. British Medical fournal, 1971, 1, 129.

Buchanan, K. D., McKiddie, M. T., Lindsay, A. C., and Manderson, W. G. (1967). Gut, 8, 325.

Burns, T. W., Bregant, R., van Peenan, H. J., and Hood, T. E. (1965). fournal of Laboratory and Clinical Medicine, 65, 927.

Cameron, A. J., Ellis, J. P., McGill, J. I., and Le Quesne, L. P. (1969). Gut, 10,825 .
Chisholm, D. J., Young, J. D., and Lazarus, L. (1969). fournal of Clinical Investigation, 48, 1453.

Dupre, J. (1964). Fournal of Physiology, 175, 58.

Dupre, J., Curtis, J. D., Unger, R. H., Waddell, R. W., and Beck, J. C. (1969). Fournal of Clinical Investigation, 48, 745.

Evensen, O. K. (1942). Acta Medica Scandinavica, Suppl. No. 126.

Fitzgerald, M. G., and Keen, H. (1964). Lancet, 1, 1325.

Griffith, G. H., Owen, G. M., Cambell, H., and Shields, R. (1968). Gastroenterology, 54, 1.

Hales, C. N., and Randle, P. J. (1963). Biochemical fournal, 88, 137.

Hall, W. H.' (1971). American Fournal of Digestive Diseases, 16, 139.
Hall, R., Bunch, G. A., and Humphrey, C. S. (1971). British Medical fournal, 3, 767.

Hobsley, M., and Le Quesne, L. P. (1960). British Medical fournal, 1, 147. Holdsworth, C. D., Turner, D., and McIntyre, N. (1969). British Medical fournal, 4, 257.

Jones, A. W., Kirk, R. S., and Bloor, K. (1970). Gut, 11, 679.

Kaess, H., Schlierf, G., and von Mikulicz-Radecki, J. G. (1970). Metabolism, $19,214$.

McIntyre, N., Holdsworth, C. D., and Turner, D. S. (1964). Lancet, 2, 20. McIntyre, N., Holdsworth, C. D., and Turner, D. S. (1965). Fournal of Clinical Endocrinology and Metabolism, 25, 1317.

Morley, G., Dewson, A., and Marks, V. (1968). Proceedings of the Association of Chemical Biochemists, 5, 43.

Oakley, N. W., et al. (1970). Clinical Science, 39, 663.

Ohgawara, H., Mizuno, Y., Tasaka, Y., and Kosaka, K. (1969). fournal of Clinical Endocrinology and Metabolism, 29, 1261.

Okada, S., Juramochi, K., Tsukahara, T., and Ooinoue, T. (1930). Archives of Internal Medicine, 45, 783.

Perley, M., and Kipnis, D. M. (1965). Fournal of Laboratory and Clinical Medicine, 66, 1009.

Perreau, P., Joubaud, F., Benbouali, A., Pithon, G., and Verger, P. (1969). Acta Gastro-Enterologica Belgica, 32, 80.

Peters, N. and Hales, C. N. (1965). Lancet, $1,1144$.

Platt, W. D., Dotti, L. B., and Beckman, R. S. (1949). Gastroenterology, 13,

Rehfeld, J. F., and Heding, L. G. (1970). British Medical fournal, 1, 706. Roholm, K. (1930). Acta Medica Scandinavica, 73, 472.

Samols, E., Tyler, J., Marri, G., and Marks, V. (1965). Lancet, 2, 1257. Sloan, J. M., MacKay, J. S., and Sheridan, B. (1970). British Medical fournal, 4, 586 .

Spearman, C. (1904). American fournal of Psychology, 15, 88.

Stout, R. W. (1968). Lancet, 2, 702.

Sullivan, M. B., and Boshell, B. R. (1964). British Medical fournal, 1, 414. Unger, R. H., and Eisentraut, A. M. (1964). Diabetes, 13, 563.

Unger, R. H., Ketterer, H., Dupre, J., and Eisentraut, A. M. (1967). fournal of Clinical Investigation, 46, 630.

Yalow, R. S., Glick, S. M., Roth, J., and Berson, S. A. (1965). Annals of the New York Academy of Sciences, 131, 357.

Young, J. D., Lazarus, L., and Chisholm, D. J. (1968). Lancet, 2, 914.

\title{
Hypertension and Hyperparathyroidism
}

\author{
F. D. ROSENTHAL, S. ROY
}

British Medical fournal, 1972, 4, 396-397

\section{Summary}

Of 40 patients with primary hyperparathyroidism 13 were hypertensive. Nine presented with hypertension and, of these, seven were discovered to have hyperparathyroidism by the routine determination of serum calcium in 900 patients referred for investigation of hypertension. The association of hypertension and hyperparathyroidism is well recognized but the cause is in doubt. The incidence of primary hyperparathyroidism in patients with hypertension is about 1 in 130 , which is considerably higher than in the general population (1 in 1,000-2,000). All patients with hypertension should have a routine serum calcium estimation. Parathyroidectomy in these otherwise asymptomatic cases may prevent renal damage.

\section{Introduction}

The clinical manifestations of hyperparathyroidism are many, and patients may present with urinary calculi, renal calcification,

Department of Medicine, Leicester Royal Infirmary, Leicester F. D. ROSENTHAL, M.D., F.R.C.P., Consultant Physician S. ROY, M.B., M.R.C.P., Senior Registrar

skeletal symptoms, or manifestations of hypercalcaemia. Occasionally on routine screening a raised serum calcium may lead to the diagnosis in patients apparently free from symptoms (Dent, 1962; Gough et al., 1971). Hypertension in hyperparathyroidism was described by Hellstrom et al. (1958). In their series of 95 patients $47(49 \%)$ had a diastolic blood pressure of $100 \mathrm{~mm} \mathrm{Hg}$ or above. George et al. (1965) found the incidence to be $20 \%$, and Pyrah et al. (1966) between 30 and 50\%.

\section{Patients and Investigations}

During the period $1960-71,40$ patients with primary hyperparathyroidism were diagnosed in Leicester. Thirty-one presented with renal stones, renal colic, or symptoms of hypercalcaemia. Four patients had diastolic blood pressure of above $110 \mathrm{~mm} \mathrm{Hg}$. All had fasting serum calcium levels of $10.4 \mathrm{mg} /$ $100 \mathrm{ml}$ or above (normal range 8.8 to $10.3 \mathrm{mg} / 100 \mathrm{ml}$.) The diagnosis was confirmed by the removal of a parathyroid adenoma in all patients except one who had parathyroid hyperplasia. In all cases the serum calcium returned to normal after operation.

In the period 1968-71 the serum calcium was measured in 900 patients presenting with diastolic hypertension of at least $110 \mathrm{~mm} \mathrm{Hg}$. Raised serum calcium levels were found in seven, none of whom had the clinical features suggestive of hyperparathyroidism or renal stones. In addition there were two 